\title{
Meat quality characteristics of high dairy genetic-merit Holstein, standard dairy genetic-merit Friesian and Charolais x Holstein-Friesian steers
}

\author{
M. McGee ${ }^{1}$, M.G. Keane ${ }^{1}$, R. Neilan ${ }^{1,2}$, P.J.Caffrey ${ }^{2}$, A.P. Moloney ${ }^{1 \dagger}$
}

${ }^{1}$ Teagasc, Animal and Grassland Research and Innovation Centre, Grange, Dunsany, Co. Meath, Ireland

${ }^{2}$ School of Agriculture and Food Science, University College Dublin, Belfield, Dublin 4, Ireland

Abstract

The increased use of Holstein genetic material in the Irish dairy herd has consequences for beef production. In all, 42 spring-born steers [14 Holsteins (HO), 14 Friesian (FR) and 14 Charolais $\times$ Holstein-Friesian (CH)] were reared to slaughter at between 26 and 37 mo of age. Carcass weight was higher and the lipid concentration of m. longissimus thoracis et lumborum was lower $(P<0.05)$ for $\mathrm{CH}$ than the dairy breeds. Overall acceptability tended to be lower $(P=0.055)$ while tenderness, texture and chewiness were lower $(P<0.05)$ for $\mathrm{CH}$ compared with the dairy breeds. The proportion of C16:1 in the total lipid tended to be lower $(P=0.055)$ for $\mathrm{CH}$ than the dairy breeds. Replacing male offspring of traditional "Irish" Friesian bulls with offspring from a genetically superior (from a dairy perspective) strain of Holstein bull had no commercially important impact on beef nutritional or eating quality.

Keywords

Beef $\cdot$ genotype $\cdot$ meat quality $\cdot$ muscle composition

\section{Introduction}

Calves born to dairy cows represent approximately $59 \%$ of male cattle born annually in Ireland (AIM, 2017). Of these, approximately $52 \%$ are the progeny of Holstein-Friesian sires (AIM, 2017). The choice of a particular Holstein-Friesian sire or strain of Holstein-Friesian reflects the priorities of dairy farmers. The national dairy breeding objective in Ireland in the 1990s [i.e., Relative Breeding Index (RBI)] included milk component traits as well as volume (Roche et al., 2018), and the importation of North American and European HolsteinFriesian genetic material changed the genetic composition of the Irish dairy herd, from predominantly British Friesian to North American and European Holstein-Friesian (Buckley et al., 2000). The production, carcass and body composition implications of the use of these high dairy genetic-merit Holstein beef calves compared with standard dairy geneticmerit Friesian and Charolais $\times$ Holstein-Friesian steers reared on a grass-based production system have been reported (McGee et al., 2005, 2007, 2008). However, there is little published information on the meat composition and quality traits of dairy herd progeny varying in dairy genetic merit compared with beef $x$ dairy progeny. It is acknowledged that dairy breeding objectives in Ireland have evolved rapidly.
Thus, in 2001, the Economic Breeding Index (EBI) was introduced as a replacement for the RBI. In addition to the existing $100 \%$ "milk traits" in the RBI further "profitability traits", like calving interval, survival, etc., were included over time such that, now, milk traits only comprise about one-third of the relative emphasis in the index (Roche et al., 2018). Nevertheless, the comparative difference in meat quality traits between the "earlier" dairy strains which differed in RBI is still of interest today since if there are differences in the sensory quality or nutritional value of beef due to the use of more extreme dairy breeds, this could compromise the ability of beef producers to service existing markets, where consumers are accustomed to beef with particular attributes of appearance, taste and texture. Alternatively, the ability to develop new markets might be enhanced if beef with different characteristics could be produced using different genotypes.

The objectives of this study were, therefore, to compare the composition and eating quality of beef from high genetic-merit Holstein and standard genetic-merit Friesian steers reared on a grass-based production system. Charolais $\times$ Holstein-Friesian steers were included in the design to provide a perspective on the magnitude of any differences between the dairy strains and a late-maturing breed when crossed with dairy cows in Ireland and to allow comparison with previous research (More O'Farrell et al., 1989). 


\section{Materials and methods}

\section{Animals and management}

Three groups of animals, balanced across sire breed, were used in this study. These consisted of (i) steers $(n=18)$ from the heavy slaughter group described by McGee et al. (2005) (Group 1), contemporaries of those animals as described by McGee et al. (2008) reared to a light (ii) (Group 2, $n=12$ ) or heavy (iii) (Group 3, $n=12$ ) slaughter weight. In brief, a total of 42 spring-born male calves [14 Holsteins (HO), 14 Friesians $(\mathrm{FR})$ and 14 Charolais $\times$ Holstein-Friesians $(\mathrm{CH})]$ were assembled in March and reared from calf-hood to slaughter. The $\mathrm{HO}$ group was the male progeny of 16 sires from high genetic-merit $(0.92$ Holstein, predominantly selected based on milk yield) dairy heifers imported from France and the Netherlands as part of a programme to evaluate various dairy cattle strains at Teagasc, Moorepark, Fermoy, Co. Cork, Ireland. The "Irish" FR animals were sourced from farms with the assistance of the South-Eastern Cattle Breeding Society (Dovea $\mathrm{Al}$ ). These calves were the progeny of 12 bulls with less than 0.13 Holstein genes and cows of similar genotype. The $\mathrm{CH}$ calves were purchased in small numbers at commercial livestock marts to be representative of the commercial population of $\mathrm{CH}$ calves generally.

After a mean rearing period of 8 wk (McGee et al., 2005), calves were turned out to pasture. They were subsequently castrated (at 9 mo of age), housed for a 156-d winter (October 25) and turned out to pasture for a second grazing season of $203 \mathrm{~d}$. At the end of the second grazing season animals in Group 1 were housed and finished on grass silage plus a daily allowance of $6 \mathrm{~kg}$ of supplementary concentrates until slaughter at 26 mo of age. At the end of the second grazing season animals in Group 2 and Group 3 were housed for a second winter period of $108 \mathrm{~d}$ after which they were used in a separate endocrinology study until the end of August. They were then put to pasture until the beginning of November, after which they were housed and offered the finishing ration described above. Group 2 animals were slaughtered at 33 mo of age and Group 3 animals at 37 mo of age.

\section{Carcass dissection}

Animals were slaughtered in a commercial meat plant (Group 1) and at the Teagasc Food Research Centre, Ashtown, Co., Dublin (Group 2 and Group 3) at a mean live weight of approximately $650 \mathrm{~kg}$ (Group 1), $629 \mathrm{~kg}$ (Group 2) and $724 \mathrm{~kg}$ (Group 3). After a 24-h period (Group 1) and 72-h (Group 2 and Group 3 ) chilling period $\left(4^{\circ} \mathrm{C}\right)$, the pistola hind quarter (i.e., the hind quarter to the fifth rib without the area on the abdominal side of $m$. iliocostalis lumborum) of the right side of each carcass was placed in a chill room $\left(4^{\circ} \mathrm{C}\right)$. For Group 1, the hinds were transported to Ashtown in a refrigerated truck.

\section{Meat quality}

At $72 \mathrm{~h}$ post-mortem, the ultimate $\mathrm{pH}$ of $m$. longissimus thoracis et lumborum (LTL) at the 10th/11th rib interface was measured using an Orion $\mathrm{pH}$ meter (Model 420A, Orion Research Inc., Boston, MA, USA) with a glass electrode (Model EC-2010-06, Reflex Sensors Ltd., Westport, Co. Mayo, Ireland). Steaks, each $2.5 \mathrm{~cm}$ thick, were cut from the right LTL starting between the 10th and 11th ribs and cutting towards the anterior. The samples used for shear force measurement and taste panel assessment, both as described by French et al. (2000), were vacuum packaged immediately, aged for $10 \mathrm{~d}$ at $4^{\circ} \mathrm{C}$ and then frozen. Those used for fatty acid (O'Sullivan et al., 2002) and proximate analysis (French et al., 2000) were frozen.

\section{Statistical analyses}

Data were subjected to analysis of variance using a model which had terms for group and genotype. Shear force and sensory data were also analysed using intramuscular fat concentration as a covariate. The relationship between shear force and tenderness was examined using linear regression.

\section{Results}

Mean carcass weight, carcass conformation and fat scores, LTL $\mathrm{pH}$ and chemical composition are shown in Table 1. Carcasses from $\mathrm{CH}$ were heavier $(P<0.05)$ than those from $\mathrm{HO}$ and $\mathrm{FR}$, which did not differ. Carcass conformation score was higher $(P<0.05)$ for $\mathrm{CH}$ than $\mathrm{HO}$ with $\mathrm{FR}$ intermediate. Carcass fat score was higher $(P<0.05)$ for $\mathrm{FR}$ than $\mathrm{HO}$ with $\mathrm{CH}$ intermediate. There was no effect $(P>0.05)$ of genotype on LTL pH or concentrations of moisture, protein and ash. The LTL from $\mathrm{CH}$ had a lower $(P<0.05)$ concentration of lipid than LTL from the dairy breeds, which did not differ. The proportion of $\mathrm{C} 12: 0$ in the total lipid was lower $(P<0.05)$ for $\mathrm{CH}$ than for $\mathrm{HO}$ which, in turn, was lower $(P<0.05)$ than for FR. The proportion of $\mathrm{C} 16: 0$ in the total lipid was lower $(P<0.05)$ for $\mathrm{HO}$ than for $\mathrm{FR}$ but similar to $\mathrm{CH}$, which did not differ from FR. There was no statistically significant effect of genotype on the proportions of the other individual fatty acids measured or on the ratios of total fatty acids.

The sensory and shear force data for the LTL muscle are summarised in Table 2. There was no statistically significant difference between $\mathrm{HO}$ and $\mathrm{FR}$ for any of the sensory attributes measured or for shear force. While shear force did not differ between $\mathrm{CH}$ and the dairy breeds, trained panellists rated LTL from $\mathrm{CH}$ lower $(P<0.05)$ for tenderness, texture, chewiness and overall acceptability $(P=0.06)$ compared with both the dairy breeds. When adjusted for differences in intramuscular fat concentration, the differences in tenderness and texture remained, but LTL from each genotype was rated similarly for 
Table 1. Characteristics of the carcass and $m$. longissimus thoracis et lumborum muscle of Holstein (HO), Friesian (FR) and Charolais $\times$ Holstein-Friesian $(\mathrm{CH})$ steers

\begin{tabular}{|c|c|c|c|c|c|}
\hline & \multicolumn{3}{|c|}{ Genotype } & \multirow[t]{2}{*}{ SED ${ }^{1}$} & \multirow[t]{2}{*}{ Significance } \\
\hline & HO & FR & $\mathrm{CH}$ & & \\
\hline Carcass weight $(\mathrm{kg})$ & $354.5^{\mathrm{a}}$ & $340.6^{\mathrm{a}}$ & $381.9^{b}$ & 9.77 & $* * *$ \\
\hline Conformation score ${ }^{2}$ & $1.2^{\mathrm{a}}$ & $2.1^{\mathrm{b}}$ & $3.0^{\circ}$ & 0.19 & *** \\
\hline Fat score ${ }^{3}$ & $3.8^{\mathrm{a}}$ & $4.3^{\mathrm{b}}$ & $4.0^{\mathrm{a}, \mathrm{b}}$ & 0.19 & * \\
\hline $\mathrm{pH}$ & 5.63 & 5.67 & 5.59 & 0.039 & \\
\hline \multicolumn{6}{|c|}{ Chemical composition ( $/ \mathrm{kg}$ ) } \\
\hline Moisture & 701 & 693 & 707 & 6.4 & \\
\hline Protein & 217 & 220 & 226 & 4.5 & \\
\hline Lipid & $78^{\mathrm{a}}$ & $77^{\mathrm{a}}$ & $58^{\mathrm{b}}$ & 7.6 & * \\
\hline Ash & 10 & 10 & 10 & 0.2 & \\
\hline \multicolumn{6}{|c|}{ Fatty acid composition (g/kg fatty acids) } \\
\hline C12:0 & $0.6^{\mathrm{a}}$ & $0.7^{\mathrm{b}}$ & $0.5^{\mathrm{c}}$ & 0.05 & * \\
\hline $\mathrm{C} 14: 0$ & 31.9 & 33.8 & 29.3 & 2.02 & \\
\hline C16:0 & $294.9^{a}$ & $311.0^{b}$ & $305.7^{\mathrm{a}, \mathrm{b}}$ & 7.48 & 0.055 \\
\hline C16:1 & 47.0 & 45.0 & 37.3 & 4.04 & \\
\hline C18:0 & 171.0 & 173.5 & 180.2 & 15.39 & \\
\hline C18:1 & 414.0 & 398.0 & 404.0 & 12.90 & \\
\hline C18:2 & 31.9 & 30.4 & 35.0 & 3.38 & \\
\hline C18.3 & 8.0 & 7.5 & 7.7 & 0.54 & \\
\hline $\mathrm{SFA}^{4}$ & 498.4 & 519.1 & 515.8 & 13.52 & \\
\hline MUFA $^{5}$ & 461.7 & 443.0 & 441.5 & 14.55 & \\
\hline PUFA $^{6}$ & 39.9 & 37.9 & 42.8 & 3.73 & \\
\hline PUFA:SFA & 0.08 & 0.07 & 0.08 & 0.007 & \\
\hline C18:2:C18:3 & 4.03 & 4.03 & 4.61 & 0.344 & \\
\hline
\end{tabular}

${ }^{1}$ Standard error of the difference.

${ }^{2}$ EU Beef Carcass Classification Scheme - Scale 1 (poorest) to 5 (best).

${ }^{3}$ EU Beef Carcass Classification Scheme - Scale 1 (leanest) to 5 (fattest).

${ }^{4}$ Total saturated fatty acids.

${ }^{5}$ Total mono-unsaturated fatty acids.

${ }^{6}$ Total poly-unsaturated fatty acids.

chewiness and overall acceptability. Shear force was negatively correlated with sensory tenderness $(r=-0.44, P<0.001)$.

\section{Discussion}

Among the criteria that determine market acceptability of beef are carcass weight/classification, gender and age of the animal at slaughter, and ultimately the sensory experience of the consumer. There has also been an increasing interest in the nutritional value of meat and in particular on its fatty acid composition, which reflects advice from health advisory agencies (e.g., World Health Organisation, 2003). Since decisions made by dairy farmers influence the type of dairy origin animals available to beef farmers, it is important to examine how changes in the type of animal might impact on their market suitability. McGee et al. (2005, 2007, 2008) reported the production and carcass characteristics of high genetic-merit Holstein-sired male cattle compared with standard "Irish" Friesian or Charolais-sired male cattle. This paper reports some aspects of meat quality from a sub-set of those animals.

The differences in carcass weight and carcass conformation and fat scores of the three genotypes are given for reference here and have been discussed in detail by McGee et al. $(2005,2008)$. The lower intramuscular fat concentration of the $\mathrm{CH}$ compared with the dairy breeds in this study is in accord with other studies comparing beef crosses with pure Friesian or Holstein-Friesian cattle (Keane and More O'Ferrall, 1992, Keane, 1994, Dunne et al., 2004). The similarity between the two dairy genotypes in both lipid and moisture content concurs with Dunne et al. (2004) who found no difference 
Table 2. Sensory characteristics and shear force of the $m$. longissimus thoracis et lumborum muscle from Holstein (HO), Friesian (FR) and Charolais $\times$ Holstein-Friesian $(\mathrm{CH})$ steers

\begin{tabular}{|c|c|c|c|c|c|}
\hline & \multicolumn{3}{|c|}{ Genotype } & \multirow[t]{2}{*}{ SED 1} & \multirow[t]{2}{*}{ Significance } \\
\hline & HO & FR & $\mathrm{CH}$ & & \\
\hline Shear force (kg) & 5.50 & 6.09 & 6.06 & 0.313 & \\
\hline \multicolumn{6}{|l|}{ Sensory assessment } \\
\hline Tenderness ${ }^{2}$ & $5.52^{\mathrm{a}}$ & $5.49^{a}$ & $4.39^{\mathrm{b}}$ & 0.315 & $* * *$ \\
\hline Texture $^{3}$ & $3.87^{\mathrm{a}}$ & $3.84^{\mathrm{a}}$ & $3.40^{\mathrm{b}}$ & 0.125 & $* * *$ \\
\hline Juiciness/moistness ${ }^{2}$ & $5.50^{\mathrm{a}}$ & $4.88^{a, b}$ & $4.58^{\mathrm{b}}$ & 0.305 & * \\
\hline Flavour $^{3}$ & 4.02 & 3.82 & 3.58 & 0.193 & \\
\hline Chewiness $^{3}$ & $3.84^{a}$ & $3.93^{\mathrm{a}}$ & $3.47^{\mathrm{b}}$ & 0.168 & * \\
\hline Overall acceptability ${ }^{3}$ & $3.78^{\mathrm{a}}$ & $3.69^{\mathrm{a}}$ & $3.38^{\mathrm{b}}$ & 0.169 & 0.055 \\
\hline \multicolumn{6}{|l|}{ Sensory assessment ${ }^{4}$} \\
\hline Tenderness $^{2}$ & $5.56^{a}$ & $5.41^{\mathrm{a}}$ & $4.44^{\mathrm{b}}$ & 0.343 & * \\
\hline Texture $^{3}$ & $3.88^{\mathrm{a}}$ & $3.82^{\mathrm{a}}$ & $3.39^{b}$ & 0.136 & * \\
\hline Juiciness/moistness ${ }^{2}$ & $5.49^{a}$ & $4.92^{\mathrm{a}, \mathrm{b}}$ & $4.59^{\mathrm{b}}$ & 0.332 & 0.057 \\
\hline Flavour $^{3}$ & 3.99 & 3.79 & 3.63 & 0.209 & \\
\hline Chewiness $^{3}$ & 3.87 & 3.94 & 3.43 & 0.181 & \\
\hline Overall acceptability ${ }^{3}$ & 3.78 & 3.65 & 3.38 & 0.183 & \\
\hline
\end{tabular}

${ }^{1}$ Standard error of the difference.

2Scale 1-8.

${ }^{3}$ Scale 1-6; a lower score denotes a more negative rating.

${ }^{4}$ Adjusted for differences in intramuscular fat concentration.

in moisture or intramuscular lipid content of the longissimus dorsi between the male progeny of two strains of high geneticmerit Friesian cows ("Irish" and "New Zealand").

Consistent with the present findings, Dunne et al. (2004) found no difference between the $\mathrm{pH}$ of the longissimus dorsi of the steer progeny of two strains of high genetic-merit Friesian cows slaughtered at either a light or heavy weight. Moreover, Sinclair et al. (2001) found no difference in the $\mathrm{pH}$ of the $m$. longissimus lumborum between purebred Holstein and Charolais steers and Lynch et al. (2002) found no significant difference in the $\mathrm{pH}$ of the longissimus dorsi between Friesian and Charolais heifers. In this study, all groups had similar preslaughter handling and were finished indoors, making them unlikely to suffer from pre-slaughter stress-related loss of glycogen. Consequently, all values were within the "normal" $\mathrm{pH}$ range (i.e., 5.4-5.8) (Viljoen et al., 2002) and there was no evidence of "dark cutting".

The fatty acid profile of LTL lipid of the dairy breeds in this study was broadly similar to that reported by Moreno et al. (2008) for the male progeny of the two strains of high genetic-merit Friesian cows described by Dunne et al. (2004) above. Moreno et al. (2008), however, found no difference in the proportion of C16:0 in LTL lipid in contrast with this study. The rather similar fatty acid profile of LTL across genotypes was not unexpected as the review of De Smet et al. (2004) concluded that breed differences in fatty acid composition while often statistically significant, are small, and in particular when compared with the potential effects of the composition of the ration consumed before slaughter. The change in the proportion of $\mathrm{C} 16: 0$ observed in this study is of little consequence from a human nutrition perspective. Nuernberg et al. (2005) reported a lower proportion of $\mathrm{C} 14: 0$ and $\mathrm{C} 16: 1$ and a higher proportion of C18:2 poly-unsaturated fatty acid (PUFA) in intramuscular lipids from Simmental compared with Holstein bulls which are consistent with the numerical differences in this study. Mills et al. (1992) reported that Holstein steers had higher C16:0 and C18:2 and lower C18:0 concentration in the longissimus muscle than Angus $\times$ Charolais $\times$ Simmental steers.

Tenderness is considered to be a major factor in the assessment of meat quality by consumers (Miller et al., 2001). In agreement with the present results, previous studies have found no difference in shear force between Friesian and Charolais-sired steers (More O'Farrell et al., 1989), purebred Holstein and Charolais steers (Sinclair et al., 2001, Christensen et al., 2011), and between Holstein and Gascon (a late-maturing breed) bulls (Bures and Barton, 2018). In contrast, Lively et al. (2005) reported a lower shear force for purebred Holstein than Charolais ( $>0.75$ ancestry) steers and Nuernberg et al. (2005) reported a lower shear force for Holstein than Simmental bulls. In this study, although not statistically significant, it is noteworthy that $\mathrm{HO}$ had a numerically lower (10\%) shear force than $\mathrm{CH}$. 
The moderate negative associations between the two measures of tenderness observed in this study are similar to many other studies (Caine et al., 2003; Keady et al., 2017), suggesting that shear force may not always be a reliable indicatory of consumer perception of tenderness. Maher et al. (2004) found no difference in sensory tenderness or overall acceptability between the steer progeny of two strains of high genetic-merit Friesian cows in agreement with this study. We are not aware of other studies that compared the eating quality of muscle from different strains of Holstein/Friesian steers. With regard to the comparison of dairy- and beef-sired steers, previous studies have reported no differences between Holstein and Charolais steers (Sinclair et al., 2001), Holstein and Simmental bulls (Nuernberg et al., 2005), Holstein and Limousin or Blonde d'Aquitaine bulls (Monson et al., 2005), in tenderness or overall acceptability. The contrast between these reports and with the tenderness data, in particular, of this study may reflect the relatively higher intramuscular fat concentration and the age of the animals. When adjusted for differences in intramuscular fat concentration, the genotype difference in tenderness remained but overall acceptability was similar, consistent with the literature cited above. This result suggests that other factors such as collagen concentration and crosslinking may have made a greater concentration to tenderness than intramuscular fat in these animals.

In conclusion, under the conditions of this study, replacing male offspring of traditional Friesian sires with offspring from a genetically superior (from a dairy perspective) strain of Holstein sire in a beef production system had no commercially important impact on beef nutritional or eating quality. While the trained sensory panel rated $\mathrm{CH}$-sired beef lower than that of the dairy-sired beef, whether the difference would be detected by untrained consumers given the lack of difference in shear force needs to be confirmed.

\section{Acknowledgements}

The authors thank T. Darby, F Collier and E. Vesey for skilled technical assistance.

\section{References}

AIM. 2017. Bovine Statistics Report, Department of Agriculture, Food and the Marine. Available online: https://www.agricultiure.gov.ie. [Accessed 22 October 2018].

Buckley, F., Dillon, P., Mee, J., Evans, R. and Veerkamp, R. 2000. Trends in genetic merit for milk production and reproductive performance. In: "Dairying 2000- Opportunities for the new millennium". Teagasc, National Dairy Conference, $16^{\text {th }}$ November 2000 , pages 43-59.
Bures, D. and Barton, L. 2018. Performance, carcass traits and meat quality of Aberdeen Angus, Gascon, Holstein and Fleckvieh finishing bulls. Livestock Science 214: 231-237.

Caine, W.R., Aalhus, J.L., Best, D.R., Dugan, M.E.R., and Jeremiah, L.E. 2003. Relationship of texture profile analysis and WarnerBratzler shear force with sensory characteristics of beef rib steaks. Meat Science 64: 333-339.

Christensen, M., Ertbjerg, P., Failla, S., Sanudo, C., Richardson, R.I, Nute, G.R., Olleta, J.L., Panea, B., Alberti, P., Juarez, M. Hocquette, J.F. and Williams, J.L. 2011. Relationship between collagen characteristics, lipid content and raw and cooked texture of meat from young bulls of fifteen European breeds. Meat Science 87: $61-65$.

CSO. 2017. Central Statistics Office. Meat Supply Balance. Available online: https://www.cso.ie [Accessed 22 October 2018].

De Smet, S., Raes, K. and Demeyer, D. 2004. Meat fatty acid composition as affected by fatness and genetic factors: A review. Animal Research 53: 81-98.

Dunne, P.G., Keane, M.G., O'Mara, F.P., Monahan, F.J. and Moloney A.P. 2004. Colour of subcutaneous adipose tissue and M. Longissimus dorsi of high index dairy and beef $x$ dairy cattle slaughtered at two liveweights as bulls and steers. Meat Science 68: 97-106.

French, P, O'Riordan, E.G., Monahan, F.J., Caffrey, P.J., Vidal, M., Mooney, M.T., Troy, D.J. and Moloney, A.P. 2000. Meat quality of steers finished on autumn grass, grass silage or concentratebased diets. Meat Science 56: 173-180.

Keady, S.M., Waters, S.M., Hamill, R.M., Dunne, P.G., Keane, M.G., Richardson, R.I., Kenny, D.A. and Moloney, A.P. 2017. Compensatory growth in crossbred Aberdeen Angus and Belgian Blue steers: Effects on the colour, shear force and sensory characteristics of longissimus muscle. Meat Science 125: 128-136.

Keane, M.G. 1994. Productivity and carcass composition of Friesian, Meuse-Rhine-Issel $(\mathrm{MRI}) \times$ Friesian and Belgian Blue $\times$ Friesian steers. Animal Production 59: 197-208.

Keane, M.G. and More O'Ferrall, G.J. 1992. Comparison of Friesian, Canadian Hereford $\times$ Friesian and Simmental $\times$ Friesian steers for growth and carcass composition. Animal Production 55: 377-387.

Lively, F.O., Moss, B.W., Keady, T.W.J., Patterson, D.C. and Gordon, A. 2005. The effect of genotype and carcass hanging method on meat quality. Proceedings 51st International Congress on Meat Science and Technology, Baltimore, USA, pages 1808-1815.

Lynch, A., Buckley, D.J., Galvin, K., Mullen, A.M., Troy D.J. and Kerry, J.P. 2002. Evaluation of rib steak colour from Friesian, Hereford and Charolais heifers pastured or overwintered prior to slaughter. Meat Science 61: 227-232.

Maher, S.C., Mullen, A.M., Keane, M.G., Buckley, D.J., Kerry, J.P. and Moloney, A.P. 2004. Variation in the eating quality of M. longissimus dorsi from Holstein-Friesian bulls and steers of New Zealand and European/American descent and Belgian Blue $\mathrm{x}$ Holstein-Friesian, slaughtered at two weights. Livestock Production Science 90: 271-277. 
McGee, M., Keane, M.G., Neilan, R., Moloney, A.P. and Caffrey, P.J. 2005. Production and carcass traits of high dairy genetic merit Holstein, standard dairy genetic merit Friesian and Charolais $\times$ Holstein-Friesian male cattle. Irish Journal of Agricultural and Food Research 44: 215-231.

McGee, M., Keane, M.G., Neilan, R., Moloney, A.P and Caffrey, P.J. 2007. Body and carcass measurements, carcass conformation and tissue distribution of high dairy genetic merit Holstein, standard dairy genetic merit Friesian and Charolais $\times$ HolsteinFriesian male cattle. Irish Journal of Agricultural and Food Research 46: 129-147.

McGee, M., Keane, M.G., Neilan, R., Moloney, A.P. and Caffrey, P.J. 2008. Non-carcass parts and carcass composition of high dairy genetic merit Holstein, standard dairy genetic merit Friesian and Charolais $\times$ Holstein-Friesian steers. Irish Journal of Agricultural and Food Research 47: 41-51.

Miller, M.F., Carr, M.A., Ramsey, C.B., Crockett, K.L. and Hoover, L.C. 2001. Consumer thresholds for establishing the value of beef tenderness. Journal of Animal Science 79: 3062-3068.

Mills, E.W., Comerford, J.W., Hollender, R., Harpster, H.W., House, B. and Henning, W.R. 1992. Meat composition and palatability of Holstein and beef steers as influenced by forage type and protein source. Journal of Animal Science 70: 2446-2451.

Monson, F., Sanudo, C. and Sierra, I. 2005. Influence of breed and ageing on the sensory meat quality and consumer acceptability in intensively reared beef. Meat Science 71: 471-479.

More O'Farrell, G.J., Joseph, R.L., Tarrant, P.V. and McGloughlin, P. 1989. Phenotypic and genetic parameters of carcass and meatquality traits in cattle. Livestock Production Science 21: 35-47.

Moreno, T., Keane, M.G., Noci, F. and Moloney, A.P. 2008. Fatty acid composition of $M$. longissimus dorsi from Holstein-Friesian steers of New Zealand and European/American descent and from Belgian Blue $x$ Holstein-Friesian steers, slaughtered at two weights/ages. Meat Science 80: 157-169.

Nuernberg, K., Dannenberger, D., Neurnberg, G., Ender, K., Voight, J., Scollan, N.D., Wood, J.D., Nute, G.R. and Richardson, R.I. 2005. Effects of a grass-based and concentrate feeding system on meat quality characteristics and fatty acid composition of longissimus muscle in different cattle breeds. Livestock Production Science 94: 137-147.

O'Sullivan, A., O'Sullivan, K., Galvin, K., Moloney, A.P., Troy, D.J. and Kerry, J.P. 2002. Grass silage versus maize silage effects on retail packaged beef quality. Journal of Animal Science 80: 1556-1563.

Roche, J.R., Berry, D.P, Bryant, A.M., Burke, C.R., Butler, S.T., Dillon, P.G., Donaghy, D.J., Horan, B., Macdonald,K.A. and Macmillan, K.L. 2018. A 100-year review: A century of change in temperate grazing dairy systems. Journal of Dairy Science 100: 1018910233.
Sinclair, K.D., Lobley G.E., Horgan G.W., Kyle, D.J., Porter, A.D., Matthews, K.R., Warkup, C.C. and Maltin, C.A. 2001. Factors influencing beef eating quality. 1 . Effects of nutritional regime and genotype on organoleptic properties and instrumental texture. Animal Science 72: 269-577.

Viljoen, H., De Kock, H. and Webb, E. 2002. Consumer acceptability of dark, firm and dry (DFD) and normal pH beef steaks. Meat Science 61: 181-185.

World Health Organisation. 2003. "Diet, Nutrition and the Prevention of Chronic Diseases", Report of the joint WHO/FAO expert consultation, Vol. 916, (Geneva). 